\title{
Trends and prevalence of overweight and obesity in primary school aged children in the Republic of Ireland from 2002-2012: a systematic review
}

\author{
Eimear Keane ${ }^{1 *}$, Patricia M Kearney ${ }^{1}$, Ivan J Perry ${ }^{1}$, Cecily C Kelleher ${ }^{2}$ and Janas M Harrington ${ }^{1}$
}

\begin{abstract}
Background: The prevalence of childhood overweight and obesity in developed countries appears to be levelling off. As trends in childhood obesity prevalence have not been examined over the past decade in the Republic of Ireland, this systematic review aims to compile and synthesise all available information on the prevalence of overweight and obesity in primary school aged children between 2002 and 2012.
\end{abstract}

Methods: Systematic review of published and grey literature containing data on objectively measured height and weight. Inclusion criteria included studies where data was collected between 2002 and 2012 from at least 200 primary school aged children in the Republic of Ireland. Database searching, Google searching, reference searching and contact with obesity experts was undertaken. Overweight, obesity and morbid obesity were defined using standard International Obesity Taskforce definitions. Study quality was assessed.

Results: Fourteen studies (16 prevalence estimates) met the inclusion criteria. The combined prevalence of overweight and obesity within the studies ranged from 20-34\%. No significant trend in overweight prevalence over time was observed $(p=0.6)$. However, there was evidence of a slight decrease in obesity prevalence over the period $(p=0.01)$, with a similar though non-significant decline in the prevalence of morbid obesity $(p=0.2)$.

Conclusion: The findings of this systematic review require cautious interpretation though the prevalence of childhood overweight and obesity in the Republic of Ireland has reached a plateau and may be falling. These findings provide some ground for optimism though the current plateau is at an unacceptably high level. Thus current population based preventive strategies need to be sustained and intensified.

Keywords: Ireland, Prevalence, Trends, Obesity, Children

\section{Background}

Globally, childhood overweight and obesity is a significant public health problem associated with a number of adverse physical and psychological consequences during childhood and in later life [1-3]. In the latter three decades of the $20^{\text {th }}$ century, a two to three fold increase in overweight and obesity prevalence in school aged children was reported in many industrialised regions including countries in North America and Western Europe [4]. By the year 2000, estimates suggested that

\footnotetext{
* Correspondence: eimear.keane@ucc.ie

'Department of Epidemiology and Public Health, University College Cork, Fourth Floor, Western Gateway Building, Western Road, Cork, Republic of Ireland

Full list of author information is available at the end of the article
}

between $25-33 \%$ of all children in many developed countries were either overweight or obese [5,6] and future projections anticipated prevalence rates would continue to increase significantly [7].

However, recent evidence from some developed countries suggests that childhood overweight and obesity prevalence rates have stabilised since the early 2000s $[8,9]$. Olds et al. [10] collated data from 467,294 children from 9 countries (including countries from Western Europe, North America, Oceania and Asia) and separately assessed overweight and obesity trends over time. The authors found that trends in both overweight and obesity prevalence appeared to be stabilising between 1995 and 2008 . Rokholm et al. [11] conducted a systematic review and 
assessed the prevalence of childhood obesity in 17 countries (including countries in Western Europe, North America and Australia) since the year 1999. While there was some conflicting evidence, overall the findings suggested that obesity prevalence had stabilised in many developed countries though patterns were less consistent amongst lower socio-economic groupings.

Perry et al. [12] collated data from three large scale national surveys on the height and weight of Irish children between 1948 and 2002. The findings indicated that the weight of Irish children had increased disproportionally to their height. In 2008, the World Health Organisation (WHO) childhood obesity surveillance initiative commenced in Ireland and this initiative will provide ongoing data on the height and weight of Irish children aged 7 [13]. However, trends in childhood overweight and obesity in the Republic of Ireland (ROI) have not been examined over the past decade. The prevalence of morbid obesity in Irish children also remains unknown. Therefore, this systematic review aims to objectively synthesise all available information on the prevalence of overweight and obesity (including morbid obesity) in primary school aged children in the ROI over a ten year period from 2002-2012.

\section{Methods}

\section{Search strategy}

The search strategy is summarised in Figure 1 with further details available in Additional file 1. Medline, EMBASE, Academic search complete and CINAHL were systematically searched for relevant literature in April and May 2013. For each database, searching was conducted using a combination of the following search terms: obesity, overweight, obese, body mass index, BMI, Ireland, Irish, child*, school children, schoolchildren, pediatr", paediar", girls, boys, prevalence, rate, trend, increase, decrease. Search terms were combined using the AND or OR operators. Limits were applied on year of publication (from 2002 onwards) and age (primary school age) of participants.

A Google search was conducted in May 2013 using the search terms: prevalence, child, obesity, Ireland. Google advanced search commands were applied using the 'site or domain' option with .ie webpage's searched only. The first 20 pages were searched for relevant literature. Publically available Irish databases or national agencies websites (Irish Social Science Data Archive, Safefood, The Health Well, Department of Health and Children's Irish child health database) known to the authors of this review and available on the Internet were

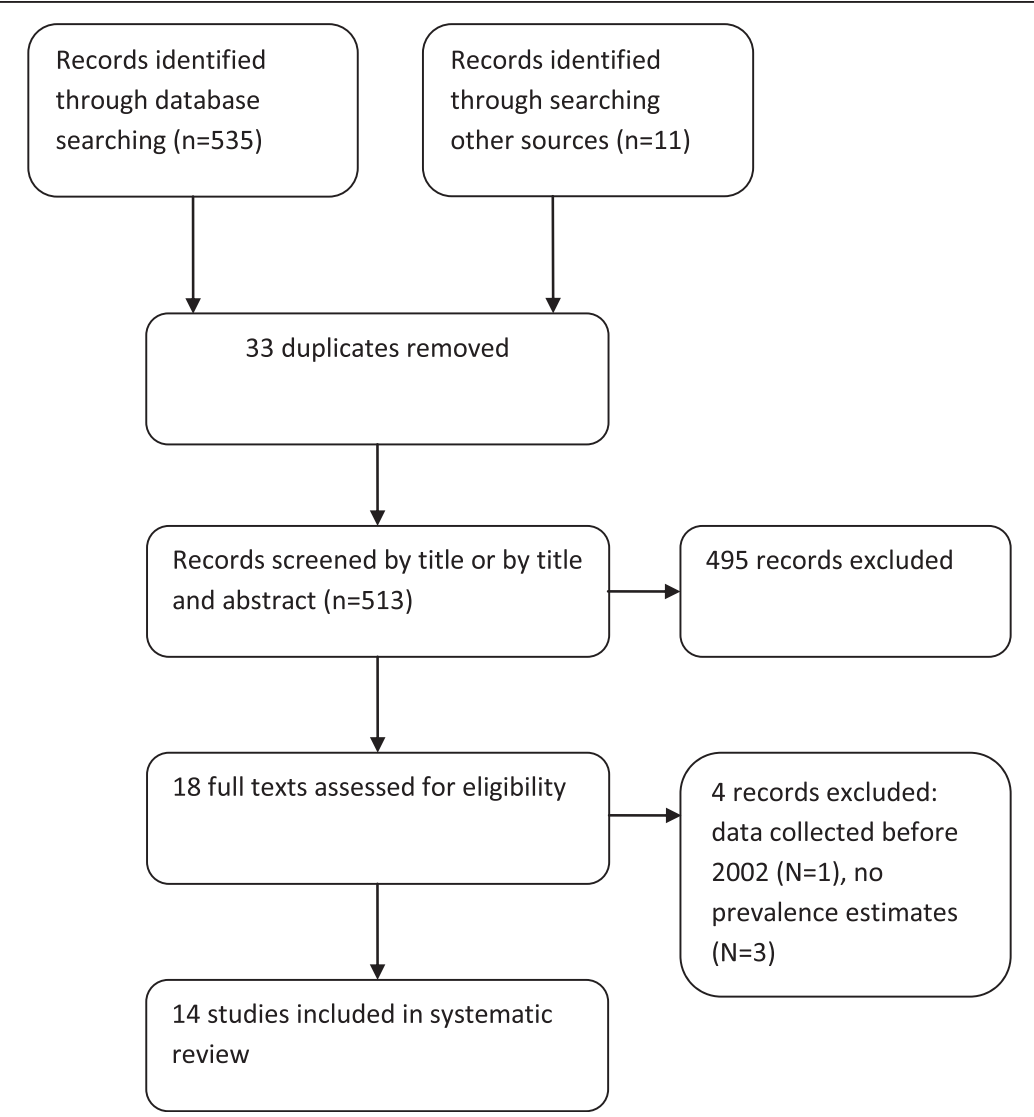

Figure 1 Flowchart of studies included in the review. 
searched for relevant literature in April and May 2013. A number of obesity experts working in Ireland were identified by the authors of this systematic review. Each expert was contacted either by email or via an announcement made at an Irish obesity action meeting held in June 2013 (http://www.safefood.eu/Professional/ Nutrition/All-island-Obesity-Action-Forum.aspx). Information was sought on any data sources not located during the database searching. Data sources known to the authors of this review were also considered for inclusion. A reference search of all eligible papers was conducted to identify additional literature. Findings from one included study (the WHO European Childhood Obesity Surveillance programme) were updated during the writing of the review and the updated findings included in the current review [14].

\section{Inclusion criteria}

Inclusion criteria for this review were as follows:

1. Studies conducted in the ROI where data collection was undertaken between 2002-2012;

2. Cross-sectional or cohort studies where height and weight were objectively measured;

3. Studies reporting overweight and obesity prevalence estimates using International Obesity Taskforce (IOTF) [15] definitions for body mass index (BMI) or where data was available to calculate BMI;

4. Studies including at least 200 children of a primary school age (approximately 4-12 years).

Peer-reviewed publications, grey literature and baseline data from population based intervention studies were considered for inclusion. Studies containing participants from Northern Ireland only, self-reported data or which reported the effect of a treatment or intervention for childhood obesity were excluded.

\section{Quality assessment and data extraction}

The methodological quality of all included studies was assessed and extracted by two independent reviewers (EK, JMH). Any disagreements were resolved by consensus. Additional file 2 provides an outline of the quality assessment criteria. Eight criteria were used which were adapted from those outlined by Radulescu et al., 2009 [16] for assessing the quality of prevalence studies. The quality of included papers were categorized as 'high' if 7-8 criteria were met, 'moderate' if 5-6 criteria were met and 'low' if 4 or less criteria were met.

\section{Statistical analysis}

Data analysis for this review was conducted in Stata 12 IC (StataCorp LP, USA). Where we were provided with raw data, children were categorised using the zbmicat function (a Stata add-on program) as normal weight, overweight or obese using age and gender specific IOTF definitions [17]. Year of data collection was ranked from oldest to newest and Cuzick's non-parametric trends test was used to conservatively test for trends in overweight and obesity prevalence over time. Trends were assessed separately for all studies, nationally based and regionally based studies. Within the included studies, trends in overweight and obesity over time were assessed separately for girls and boys. The included studies were grouped into 3 independent categories based on the age range of the participating children as 4-7.9 years only, 8-13.9 year only or 4-13.9 years. Trends in overweight and obesity were then assessed separately within each of the age groups. We had access to raw data from three included studies, [18] [Keane et al., unpublished observations] [HSE Meath, unpublished observations] to estimate the prevalence of morbid obesity (BMI cut-off of $35 \mathrm{~km} / \mathrm{m}^{2}$ ) using extended IOTF definitions [19]. A fourth study with available data was excluded as height and weight measures were truncated [20]. Children were classified as morbidly obese based on gender and 6 month age category.

\section{Results}

\section{Identification and selection of studies}

Five hundred and thirty five titles were retrieved from electronic database searching and 11 from the other sources searched. Duplicate titles were removed $(\mathrm{N}=33)$ and 513 titles/abstracts were reviewed and considered for inclusion. After initial screening of titles and abstracts, 19 full texts were retrieved and read for relevance. Electronic database searching resulted in 8 studies being identified for inclusion, of which one study was updated during the writing of this systematic review. One further relevant study was identified during reference searching, 3 from contact with obesity experts and 2 from the authors of this reviews awareness of other grey literature sources. Overall, 14 studies (with 16 prevalence estimates reported in 15 papers) met all the inclusion criteria. Figure 1 displays the results of the search strategy.

\section{Description of included studies}

Table 1 describes each of the included studies. The included studies were primarily cross-sectional. One study was a retrospective cohort study and two studies were baseline findings from intervention studies. Four studies (6 prevalence estimates) were based on national samples whereas 10 were regional samples. The sample sizes ranged from 204 to 14,036. Table 2 contains details on the methods of measurement and the limitations (which were identified by the authors of this review) of each study. Of the included studies, 5 studies were considered to be of 'high' quality, 9 of 'moderate' quality and 1 of 
Table 1 Descriptive information of included studies

\begin{tabular}{|c|c|c|c|c|c|c|c|c|c|c|}
\hline Author & $\begin{array}{l}\text { Data } \\
\text { collection } \\
\text { years }\end{array}$ & $\begin{array}{l}\text { Estimating } \\
\text { prevalence } \\
\text { primary aim } \\
\text { of study }\end{array}$ & $\begin{array}{l}\text { Sample } \\
\text { size\# }\end{array}$ & $\begin{array}{l}\text { National or } \\
\text { regional } \\
\text { data }\end{array}$ & Age & Setting & Response rate & Design & Sampling & $\begin{array}{l}\text { Study qualit } \\
\text { (out of 8) }\end{array}$ \\
\hline \multicolumn{11}{|c|}{ Nationally based data } \\
\hline Whelton et al. [21] & $2001-2002$ & Yes & 14036 & National & $4-13$ & $\begin{array}{l}\text { Primary } \\
\text { schools }\end{array}$ & $68 \%$ of children & Cross-sectional & $\begin{array}{l}\text { Clustered sampling with } \\
\text { schools as the clustering unit. } \\
\text { Children were randomly } \\
\text { selected on the basis of age, } \\
\text { gender, location of school } \\
\text { and water type. Primary } \\
\text { school children in junior } \\
\text { infants, second and sixth } \\
\text { class (year 1, } 4 \text { \& } 8 \text { of } \\
\text { enrolment) were invited to } \\
\text { take part }\end{array}$ & 6 \\
\hline O'Neill et al. [22] & 2003-2004 & Yes & 596 & National & $5-12$ & $\begin{array}{l}\text { Primary } \\
\text { schools }\end{array}$ & $66 \%$ of children & Cross-sectional & $\begin{array}{l}\text { A list of primary schools was } \\
\text { obtained from the Dept of } \\
\text { Education and Science. } \\
\text { Schools were categorised by } \\
\text { location, gender, size and } \\
\text { disadvantaged status. Schools } \\
\text { were randomly selected from } \\
\text { each category and children } \\
\text { randomly selected and } \\
\text { invited to take part }\end{array}$ & 5 \\
\hline $\begin{array}{l}\text { Layte \& McCrory } \\
\text { [23] }\end{array}$ & $2007-2008$ & Yes & 8136 & National & $9.0-9.9$ & Home & $57 \%$ of children & $\begin{array}{l}\text { Cross-sectional analysis } \\
\text { of a longitudinal study }\end{array}$ & $\begin{array}{l}\text { In stage one, primary schools } \\
\text { were randomly selected } \\
\text { using a probability } \\
\text { proportionate to size (PPS) } \\
\text { sampling method and in } \\
\text { stage two a random sample } \\
\text { of age eligible children from } \\
\text { within each school were } \\
\text { invited to take part }\end{array}$ & 7 \\
\hline Heavey et al. [13] & 2008 & Yes & 2420 & National & $7.0-7.9$ & $\begin{array}{l}\text { Primary } \\
\text { schools }\end{array}$ & $72 \%$ of children & $\begin{array}{l}\text { Cross-sectional, round } 1 \\
\text { of WHO COSI programme }\end{array}$ & $\begin{array}{l}\text { A nationally representative } \\
\text { sample of primary schools } \\
\text { were selected using a PPS } \\
\text { sampling strategy. Children in } \\
\text { first class (year } 3 \text { of } \\
\text { enrolment) were recruited to } \\
\text { participate. One class of first } \\
\text { class children were selected } \\
\text { from large schools }\end{array}$ & 7 \\
\hline
\end{tabular}


Table 1 Descriptive information of included studies (Continued)

Heinen et al. [14] $2010 \quad$ Yes

996

$7.0-7.7$

Primary $64 \%$ of children

Cross-sectional, round 2

Schools who took part in

$55 \%$ of children schools cross-sectional, round 3 of WHO COSI programme

\section{Regionally based data}

McMaster et al. 2001-2002 Yes [24]

Harrison et al. [25] 2003

No

Evans et al. [26]

312

328

\section{Regional}

(Counties Leitrim

and Cavan)

\section{Regional}

(South-East of

Ireland)

\section{9-11}

11

$$
\text { schools }
$$

$\%$ of children

\section{Baseline findings from a}

health education interventior

sou

round 1 [12] of this

surveillance initiative were

invited to take part in round

2. Only children aged 7 in

first class were considered in

this current analysis. One

class of first class children

were selected from large

schools

Schools who took part in

round 1 [12] of this

surveillance initiative were

invited to take part in round

3. Only children aged 7 in

first class were considered in

this current analysis. One

class of first class children

were selected from large

schools

All senior infants (year 2 of enrolment) from all schools in the former North Western Health Board area. Paper copies of school health

records were retrospectively

hand searched for height and

weight data in March 2003

Schools in areas of social

disadvantage located in the

South East of Ireland were

children from $4^{\text {th }}$ class (year 6

of enrolment) were invited to

partake

All children from all 189

primary schools in County

Mayo had height and weight

measures taken as part of the

school health check between

February 2005 and June 2008 
Table 1 Descriptive information of included studies (Continued)

\begin{tabular}{|c|c|c|c|c|c|c|c|c|c|c|}
\hline Barron et al. [27] & 2007 & Yes & 969 & $\begin{array}{l}\text { Regional } \\
\text { (County Kildare) }\end{array}$ & $4.5-13.5$ & $\begin{array}{l}\text { Primary } \\
\text { schools }\end{array}$ & $83 \%$ of children & Cross-sectional & $\begin{array}{l}\text { Data collected from } 2 \text { single } \\
\text { sex primary schools in a } \\
\text { town in County Kildare as } \\
\text { part of a larger research } \\
\text { project }\end{array}$ & 5 \\
\hline Murrin et al. [28] & 2007-2008 & No & $\begin{array}{l}529 \text { (at } \\
\text { follow up) }\end{array}$ & $\begin{array}{l}\text { Regional data } \\
\text { (Counties Dublin } \\
\text { and Galway) }\end{array}$ & $5-7$ & Home & $\begin{array}{l}62 \% \text { of mothers at } \\
\text { follow-up }\end{array}$ & $\begin{array}{l}\text { Cross-sectional analysis of a } \\
\text { prospective observational } \\
\text { cross-generational linkage } \\
\text { cohort }\end{array}$ & $\begin{array}{l}\text { Sample of } 1124 \text { expectant } \\
\text { mothers recruited at } 1^{\text {st }} \\
\text { antenatal hospital visit in } 2 \\
\text { hospitals over an } 18 \text { month } \\
\text { period from 2001-2003 [29] }\end{array}$ & 7 \\
\hline Belton et al. [30] & 2008 & No & 301 & $\begin{array}{l}\text { Regional } \\
\text { (greater Dublin) }\end{array}$ & $6-9$ & $\begin{array}{l}\text { Primary } \\
\text { schools }\end{array}$ & $97 \%$ of children & Cross-sectional & $\begin{array}{l}\text { Four mixed gender schools } \\
\text { from the greater Dublin area } \\
\text { were selected to take part in } \\
\text { the study }\end{array}$ & 3 \\
\hline Fitzgerald, [31] & 2008-2009 & No & 204 & $\begin{array}{l}\text { Regional } \\
\text { (West of Ireland) }\end{array}$ & $9-12$ & $\begin{array}{l}\text { Primary } \\
\text { schools }\end{array}$ & $58 \%$ of children & Cross-sectional & $\begin{array}{l}\text { Primary schools were } \\
\text { randomly selected from the } \\
\text { Department of Education and } \\
\text { Science list of schools and } \\
\text { invited to take part in the } \\
\text { study. All children in } 4^{\text {th }} \text { to } \\
6^{\text {th }} \text { class (years } 6-8 \text {, of } \\
\text { enrolment) were invited to } \\
\text { take part }\end{array}$ & 6 \\
\hline $\begin{array}{l}\text { HSE Meath, } \\
2009 \text { (unpublished } \\
\text { observations) }\end{array}$ & 2009 & Yes & 1468 & $\begin{array}{l}\text { Regional } \\
\text { (County Meath) }\end{array}$ & $11-13$ & $\begin{array}{l}\text { Primary } \\
\text { schools }\end{array}$ & $63 \%$ of children & Cross-sectional & $\begin{array}{l}\text { A complete sample of } \\
\text { primary schools from County } \\
\text { Meath were invited to } \\
\text { partake and all children in } 6^{\text {th }} \\
\text { class (year } 8 \text { of enrolment) of } \\
\text { participating schools invited } \\
\text { to take part }\end{array}$ & 6 \\
\hline $\begin{array}{l}\text { Hollywood et al. } \\
\text { [32] }\end{array}$ & 2009 & No & 537 & $\begin{array}{l}\text { Regional } \\
\text { (County Dublin) }\end{array}$ & $4-12$ & $\begin{array}{l}\text { Primary } \\
\text { schools }\end{array}$ & $\begin{array}{l}\text { Details not } \\
\text { provided }\end{array}$ & $\begin{array}{l}\text { Baseline findings from a } \\
\text { prospective cohort study }\end{array}$ & $\begin{array}{l}\text { Primary school children from } \\
\text { urban disadvantaged areas } \\
\text { located in Revitalising Areas } \\
\text { by Planning Investment and } \\
\text { Development (RAPID) areas } \\
\text { in Dublin took part in study. } \\
\text { All children in Junior infants } \\
\text { to } 5^{\text {th }} \text { class (year } 1-7 \text { of } \\
\text { enrolment) were invited to } \\
\text { take part }\end{array}$ & 5 \\
\hline
\end{tabular}


Table 1 Descriptive information of included studies (Continued)

2012-2013 Yes

1068

Regional

(County Cork)

Primary $65 \%$ of children

Cross-sectional

schools

A list of primary schools was

Elained from the Dept of

Education and Science

recruited using a PPS sample

(with further purposive

sampling) of Cork city

primary schools and all rural

schools from one area in

Cork County were invited to

partake. All children in $3^{\text {rd }}$

and $4^{\text {th }}$ class (year 5 and 6 of

enrolment) were invited to

take part

\#Sample sizes only include valid number of age eligible participants who provided valid objective height and weight measures. 
Table 2 Details on method of measurements and limitations of the included studies

\begin{tabular}{|c|c|c|c|c|c|c|}
\hline Author & $\begin{array}{l}\text { Data collection } \\
\text { year(s) }\end{array}$ & Height measure & Weight measure & Method of measurement & Measurement personnel & Limitations^ \\
\hline \multicolumn{7}{|c|}{ Nationally based data } \\
\hline $\begin{array}{l}\text { Whelton et al. } \\
\text { [21] }\end{array}$ & $2001-2002$ & $\begin{array}{l}\text { Leicester portable height } \\
\text { measure }\end{array}$ & Soehnle 7403 Mediscale & $\begin{array}{l}\text { Height was measured to the } \\
\text { nearest } 1 \text { decimal point in } \\
\text { centimetres }(\mathrm{cm}) \text { and weight } \\
\text { to the nearest } 1 \text { decimal } \\
\text { point in kilograms }(\mathrm{kg}) \text {. } \\
\text { Shoes, heavy clothing and } \\
\text { headgear were removed for } \\
\text { measures }\end{array}$ & $\begin{array}{l}\text { Trained researchers took } \\
\text { measures using a standard } \\
\text { protocol }\end{array}$ & $\begin{array}{l}\text { Response rate not adequate } \\
\text { and no information given on } \\
\text { non-responders }\end{array}$ \\
\hline O’Neill et al. [22] & 2003-2004 & $\begin{array}{l}\text { SECA Leicester height } \\
\text { measure }\end{array}$ & SECA 770 digital weight scales & $\begin{array}{l}\text { Height was measured in the } \\
\text { Frankfurt plane position to } \\
\text { the last complete millimetre } \\
(\mathrm{mm}) \text { and weight to the } \\
\text { nearest } 0.1 \mathrm{~kg} \text {. Light indoor } \\
\text { clothing was worn for } \\
\text { measures without shoes, hair } \\
\text { ornaments, pony tails } \\
\text { undone and empty pockets }\end{array}$ & $\begin{array}{l}\text { Qualified nutritionists took } \\
\text { measures }\end{array}$ & $\begin{array}{l}\text { Response rate not adequate, } \\
\text { no information given on } \\
\text { non-responders and methods } \\
\text { to reduce observer bias not } \\
\text { outlined }\end{array}$ \\
\hline $\begin{array}{l}\text { Layte \& McCrory, } \\
\text { [23] }\end{array}$ & $2007-2008$ & $\begin{array}{l}\text { Leicester portable height } \\
\text { measure }\end{array}$ & SECA 761 flat mechanic scales & $\begin{array}{l}\text { Height was measured to the } \\
\text { nearest } \mathrm{mm} \text { and weight to } \\
\text { the nearest } 0.5 \mathrm{~kg} \text {. Light } \\
\text { clothing was worn for } \\
\text { measures }\end{array}$ & $\begin{array}{l}\text { Trained researchers took } \\
\text { measures }\end{array}$ & $\begin{array}{l}\text { Response rate not adequate } \\
\text { and no information given on } \\
\text { non-responders** }\end{array}$ \\
\hline Heavey et al. [12] & 2008 & $\begin{array}{l}\text { SECA } 214 \text { portable } \\
\text { stadiometer }\end{array}$ & SECA 872 weighing scales & $\begin{array}{l}\text { Height was measured to the } \\
\text { last complete mm and } \\
\text { weight to the nearest } 0.1 \mathrm{~kg} \text {. } \\
\text { Light indoor clothing was } \\
\text { worn for measures without } \\
\text { shoes, hair ornaments, pony } \\
\text { tails undone and empty } \\
\text { pockets }\end{array}$ & $\begin{array}{l}\text { Trained researchers took } \\
\text { measures using a standard } \\
\text { protocol }\end{array}$ & $\begin{array}{l}\text { Response rate not adequate } \\
\text { and no information given on } \\
\text { non-responders }\end{array}$ \\
\hline Heinen et al. [14] & 2010 & $\begin{array}{l}\text { SECA } 214 \text { portable } \\
\text { stadiometer }\end{array}$ & SECA 872 weighing scales & $\begin{array}{l}\text { Height was measured to the } \\
\text { last complete mm and } \\
\text { weight to the nearest } 0.1 \mathrm{~kg} \text {. } \\
\text { Light indoor clothing was } \\
\text { worn for measures without } \\
\text { shoes, hair ornaments, pony } \\
\text { tails undone and empty } \\
\text { pockets }\end{array}$ & $\begin{array}{l}\text { Trained researchers took } \\
\text { measures using a standard } \\
\text { protocol }\end{array}$ & $\begin{array}{l}\text { Response rate not adequate } \\
\text { and no information given on } \\
\text { non-responders }\end{array}$ \\
\hline
\end{tabular}


Table 2 Details on method of measurements and limitations of the included studies (Continued)

\begin{tabular}{|c|c|c|c|c|c|c|}
\hline Heinen et al. [14] & 2012 & Leicester height measure & HD-305 Tanita weighing scales & $\begin{array}{l}\text { Height was measured to the } \\
\text { last complete mm and } \\
\text { weight to the nearest } 0.1 \mathrm{~kg} \text {. } \\
\text { Light indoor clothing was } \\
\text { worn for measures without } \\
\text { shoes, hair ornaments, pony } \\
\text { tails undone and empty } \\
\text { pockets }\end{array}$ & $\begin{array}{l}\text { Trained researchers took } \\
\text { measures using a standard } \\
\text { protocol }\end{array}$ & $\begin{array}{l}\text { Response rate not adequate } \\
\text { and no information given on } \\
\text { non-responders }\end{array}$ \\
\hline \multicolumn{7}{|c|}{ Regionally based data } \\
\hline $\begin{array}{l}\text { McMaster et al. } \\
\text { [24] }\end{array}$ & 2001-2002 & Leicester height measure & Hansen digital weight scales & $\begin{array}{l}\text { Height measured to the } \\
\text { nearest } 0.5 \mathrm{~cm} \text { and weight to } \\
\text { the nearest } 500 \mathrm{~g} \text {. Light } \\
\text { clothing was worn for } \\
\text { measures without shoes, } \\
\text { jackets and headgear }\end{array}$ & $\begin{array}{l}\text { Two school nurses took } \\
\text { measures using a standard } \\
\text { protocol }\end{array}$ & $\begin{array}{l}\text { No information given on } \\
\text { non-responders }\end{array}$ \\
\hline $\begin{array}{l}\text { Harrison et al. } \\
{[25]}\end{array}$ & 2003 & $\begin{array}{l}\text { Seca Leicester height } \\
\text { measure }\end{array}$ & Seca digital floor scales & $\begin{array}{l}\text { Children wore light clothing, } \\
\text { without shoes for measures }\end{array}$ & $\begin{array}{l}\text { Researchers were trained in } \\
\text { anthropometry }\end{array}$ & $\begin{array}{l}\text { Sampling method unclear, } \\
\text { no information given on } \\
\text { non-responders and not } \\
\text { enough detail provided on } \\
\text { method of measurement }\end{array}$ \\
\hline $\begin{array}{l}\text { Evans et al. } \\
{[26]}\end{array}$ & 2004-2007 & Leicester height measure & Tanita solar weight scales & $\begin{array}{l}\text { Height was measured to the } \\
\text { nearest } 0.1 \mathrm{~cm} \text { and weight } \\
\text { to nearest } 0.1 \mathrm{~kg} \text { using a } \\
\text { standard protocol [33] }\end{array}$ & $\begin{array}{l}\text { Trained public health nurses } \\
\text { took measures. Intra-observer } \\
\text { variability was measured }\end{array}$ & $\begin{array}{l}\text { No information given on } \\
\text { non-responders }\end{array}$ \\
\hline $\begin{array}{l}\text { Barron et al. } \\
\text { [27] }\end{array}$ & 2007 & Leicester height measure & $\begin{array}{l}\text { Tanita WB-100 digital medical } \\
\text { weighing scales }\end{array}$ & $\begin{array}{l}\text { Children wore tracksuits, } \\
\text { without shoes for measures }\end{array}$ & $\begin{array}{l}\text { One qualified paediatric } \\
\text { nurse took all measures }\end{array}$ & $\begin{array}{l}\text { Sampling method used not } \\
\text { clear, no information given } \\
\text { on non-responders and not } \\
\text { enough detail provided on } \\
\text { method of measurement }\end{array}$ \\
\hline $\begin{array}{l}\text { Murrin et al. } \\
\text { [28] }\end{array}$ & $2007-2008$ & Leicester height measure & $\begin{array}{l}\text { Tanita digital weight scales } \\
\text { model HD305 }\end{array}$ & $\begin{array}{l}\text { Height was measured to the } \\
\text { nearest } 1 \mathrm{~cm} \text { and weight to } \\
\text { the nearest } 0.1 \mathrm{~kg} \text {. A standard } \\
\text { protocol was used }\end{array}$ & $\begin{array}{l}\text { Trained researchers took } \\
\text { measures using standard } \\
\text { procedures }\end{array}$ & Response rate not adequate \\
\hline $\begin{array}{l}\text { Belton et al. } \\
\text { [30] }\end{array}$ & 2008 & $\begin{array}{l}\text { SECA Leicester height } \\
\text { measure }\end{array}$ & SECA heavy duty scales & No details given & No details given & $\begin{array}{l}\text { Sampling method unclear, } \\
\text { no information given on } \\
\text { non-responders, height and } \\
\text { weight measurements } \\
\text { methods used not described, } \\
\text { inadequate detail on equip- } \\
\text { ment used and efforts to re- } \\
\text { duce observer bias not stated }\end{array}$ \\
\hline $\begin{array}{l}\text { Fitzgerald, } \\
2010[31]\end{array}$ & 2008-2009 & Leicester height measure & Seca 899 weight scales & $\begin{array}{l}\text { Height was measured to the } \\
\text { nearest } 0.1 \mathrm{~cm} \text { in the } \\
\text { Frankfurt plane position and } \\
\text { weight to the nearest } 0.1 \mathrm{~kg} \text {. } \\
\text { Measures were taken without } \\
\text { heavy clothing and shoes }\end{array}$ & $\begin{array}{l}\text { Standard procedures were } \\
\text { used. Intra observer variability } \\
\text { was tested }\end{array}$ & $\begin{array}{l}\text { Response rate not adequate } \\
\text { and no information given on } \\
\text { non-responders }\end{array}$ \\
\hline
\end{tabular}




\section{Table 2 Details on method of measurements and limitations of the included studies (Continued)}

\begin{tabular}{|c|c|c|c|c|c|c|}
\hline $\begin{array}{l}\text { HSE Meath, } 2009 \\
\text { (unpublished } \\
\text { observations) }\end{array}$ & 2009 & Leicester height measure & Soehnle 7403 Mediscale & $\begin{array}{l}\text { Height was measured in the } \\
\text { Frankfurt plane position to } \\
\text { the nearest } 1 \text { decimal point } \\
\text { in } \mathrm{cm} \text { and weight to the } \\
\text { nearest } 1 \text { decimal point in } \mathrm{kg} \text {. } \\
\text { Measures were taken without } \\
\text { shoes and without excessive } \\
\text { clothing }\end{array}$ & $\begin{array}{l}\text { Researchers trained prior to } \\
\text { data collection. Inter } \\
\text { examiner agreement was } \\
\text { tested }\end{array}$ & $\begin{array}{l}\text { Response rate not adequate } \\
\text { and no information given on } \\
\text { non-responders }\end{array}$ \\
\hline $\begin{array}{l}\text { Hollywood et al. } \\
\text { [32] }\end{array}$ & 2009 & $\begin{array}{l}\text { SECA Leicester portable } \\
\text { height measure }\end{array}$ & SECA 875 digital flat scales & $\begin{array}{l}\text { Height was measured in the } \\
\text { Frankfurt plane position. } \\
\text { Measures were taken in } \\
\text { stockings without heavy } \\
\text { outdoor clothing }\end{array}$ & $\begin{array}{l}\text { One trained children's nurse } \\
\text { took all the measures }\end{array}$ & $\begin{array}{l}\text { Sampling method unclear, } \\
\text { response rate not adequate, } \\
\text { no information given on } \\
\text { non-responders and not } \\
\text { enough detail provided on } \\
\text { method of measurement }\end{array}$ \\
\hline $\begin{array}{l}\text { Keane et al. } 2013 \\
\text { (unpublished } \\
\text { observations) }\end{array}$ & $2012-2013$ & $\begin{array}{l}\text { Leicester portable height } \\
\text { measure }\end{array}$ & Tanita WB100MA mechanic scales & $\begin{array}{l}\text { Height was measured in the } \\
\text { Frankfurt plane position to } \\
\text { the nearest } \mathrm{mm} \text { and weight } \\
\text { to the nearest } 0.1 \mathrm{~kg} \text {. } \\
\text { Measures were taken without } \\
\text { shoes and in light clothing }\end{array}$ & $\begin{array}{l}\text { Trained researchers took } \\
\text { measures using standard } \\
\text { procedures }\end{array}$ & $\begin{array}{l}\text { Response rate not adequate } \\
\text { and no information given on } \\
\text { non-responders }\end{array}$ \\
\hline
\end{tabular}

**The data was probability weighted prior to analysis to account for the complex sampling design. This involved the structural adjustment of the study sample to the population level whilst maintaining the case base

of participating children, ^ The limitations outlined in this table were identified by the authors of this systematic review during critical appraisal of each study. 
'low' quality. Additional file 2 contains details on the critical appraisal of each included study. Overall, the combined prevalence of overweight and obesity in the national and regional studies ranged from $20-26 \%$ and $21-34 \%$ respectively.

\section{Prevalence of overweight and trends over time}

Figure 2 and table 3 describe the prevalence of overweight and obesity within each included study. Within the national and regional based studies, the prevalence of overweight ranged from $15-19 \%$ and $15-26 \%$ respectively. The prevalence of overweight ranged from $17-21 \%, 15-26 \%$ and $15 \%$ within the 'high', 'moderate' and 'low' quality studies. No significant trend in overweight prevalence was observed over time among all included studies $(\mathrm{p}=0.6)$, national studies $(\mathrm{p}=0.09)$ or regional studies $(\mathrm{p}=0.8)$.

\section{Prevalence of obesity and trends over time}

The prevalence of obesity ranged from $4-7 \%$ in the nationally based studies. The prevalence of obesity ranged from $5-11 \%$ in the regional studies. The prevalence of obesity ranged from $7-9 \%, 4-11 \%$ and $6 \%$ within the 'high', 'moderate' and 'low' quality studies. A small, significant declining trend in obesity prevalence was observed over time when all studies were reviewed $(\mathrm{p}=0.01)$. No

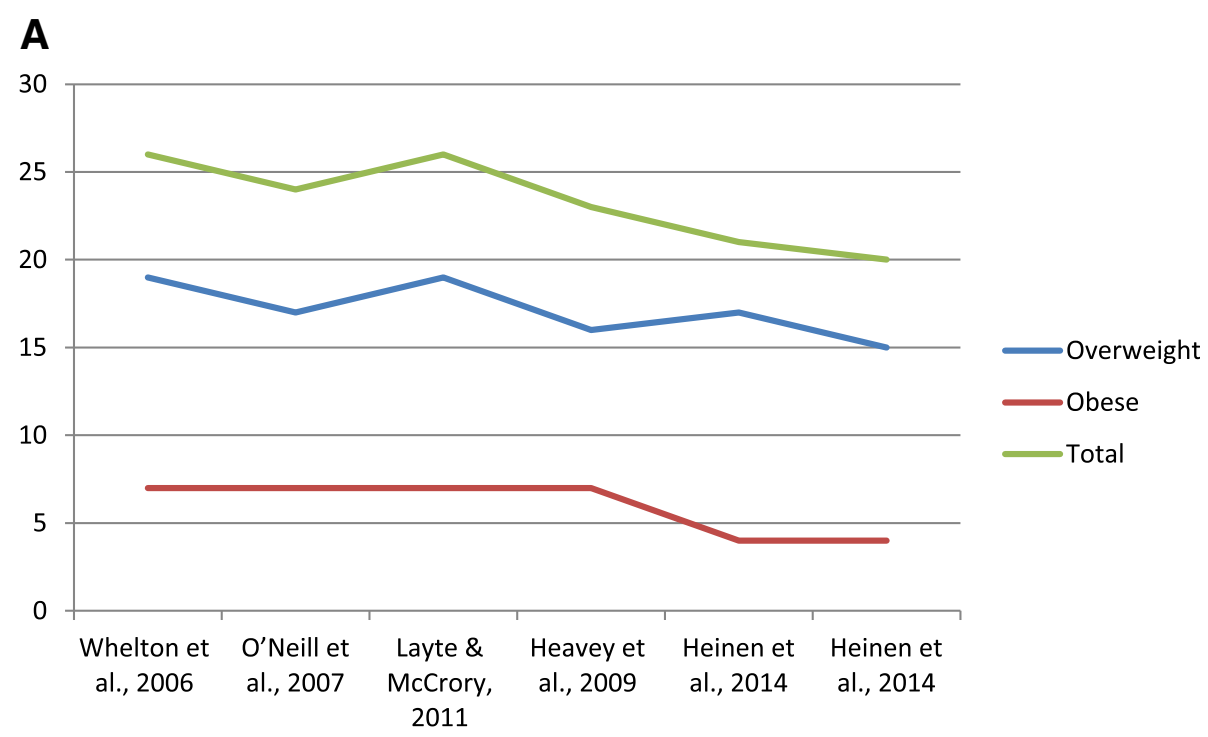

B

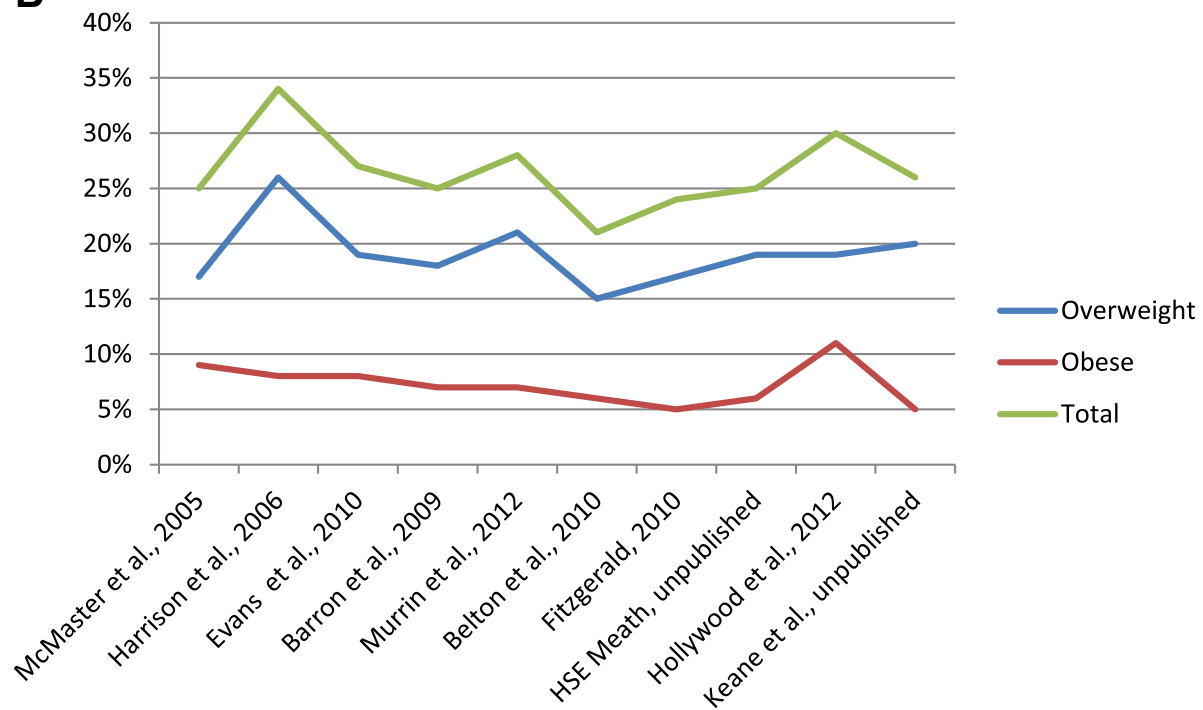

Figure 2 Prevalence of childhood overweight and obesity within the (A) nationally and (B) regionally based studies. Studies are presented by year of data collection. The study on the left represents the prevalence of overweight and obesity from the study which collected data least recently. The study which collected data most recently is presented on the right. 
Table 3 Prevalence of overweight and obesity in the included studies"

\begin{tabular}{|c|c|c|c|c|c|c|c|c|c|c|c|c|}
\hline \multirow[t]{2}{*}{ Study } & \multirow[t]{2}{*}{$\begin{array}{l}\text { Data collection } \\
\text { year(s) }\end{array}$} & \multirow[t]{2}{*}{ Sample size } & \multirow[t]{2}{*}{ Age range } & \multicolumn{3}{|c|}{$\begin{array}{l}\text { Prevalence } \\
\text { of overweight }\end{array}$} & \multicolumn{3}{|c|}{$\begin{array}{l}\text { Prevalence of obesity } \\
\text { (including morbid obesity) }\end{array}$} & \multicolumn{3}{|c|}{$\begin{array}{l}\text { Prevalence of } \\
\text { overweight and obesity }\end{array}$} \\
\hline & & & & Boys (\%) & Girls (\%) & Total (\%) & Boys (\%) & Girls (\%) & Total (\%) & Boys (\%) & Girls (\%) & Total (\% \\
\hline \multicolumn{13}{|l|}{ Nationally based data } \\
\hline Whelton et al.. [21] & $2001-2002$ & 14036 & $4-13$ & $17 \%$ & $21 \%$ & $19 \%$ & $6 \%$ & $8 \%$ & $7 \%$ & $23 \%$ & $29 \%$ & $26 \%$ \\
\hline O’Neill et al. [22] & 2003-2004 & 596 & $5-12$ & $15 \%$ & $20 \%$ & $17 \%$ & $4 \%$ & $9 \%$ & $7 \%$ & $19 \%$ & $29 \%$ & $24 \%$ \\
\hline Layte \& McCrory [23] & $2007-2008$ & 8136 & $9.0-9.9$ & $17 \%$ & $22 \%$ & $19 \%$ & $5 \%$ & $8 \%$ & $7 \%$ & $22 \%$ & $30 \%$ & $26 \%$ \\
\hline Heavey et al. [13] & 2008 & 2420 & $7.0-7.9$ & $13 \%$ & $19 \%$ & $16 \%$ & $5 \%$ & $8 \%$ & $7 \%$ & $18 \%$ & $27 \%$ & $23 \%$ \\
\hline Heinen et al.^^ [14] & 2010 & 1011 & $7.0-7.7$ & $14 \%$ & $20 \%$ & $17 \%$ & $4 \%$ & $5 \%$ & $4 \%$ & $18 \%$ & $24 \%$ & $21 \%$ \\
\hline Heinen et al.^^ [14] & 2012 & 1002 & $7.0-7.7$ & $14 \%$ & $17 \%$ & $15 \%$ & $3 \%$ & $5 \%$ & $4 \%$ & $17 \%$ & $22 \%$ & $20 \%$ \\
\hline \multicolumn{13}{|l|}{ Regionally based data } \\
\hline McMaster et al., 2005 [24] & $2001-2002$ & 328 & $4.2-7.9$ & $16 \%$ & $18 \%$ & $17 \%$ & $9 \%$ & $8 \%$ & $9 \%$ & $25 \%$ & $26 \%$ & $25 \%$ \\
\hline Harrison et al.^ [25] & 2003 & 312 & $9-11$ & $27 \%$ & $24 \%$ & $26 \%$ & $7 \%$ & $9 \%$ & $8 \%$ & $34 \%$ & $33 \%$ & $34 \%$ \\
\hline Evans et al. [26] & 2004-2007 & 3493 & $6.0-6.9$ & $17 \%$ & $22 \%$ & $19 \%$ & $6 \%$ & $9 \%$ & $8 \%$ & $23 \%$ & $31 \%$ & $27 \%$ \\
\hline Barron et al. [27] & 2007 & 969 & $4.5-13.5$ & $18 \%$ & $18 \%$ & $18 \%$ & $7 \%$ & $7 \%$ & $7 \%$ & $24 \%$ & $25 \%$ & $25 \%$ \\
\hline Murrin et al. [28] & 2007-2008 & 529 & $5-7$ & $19 \%$ & $23 \%$ & $21 \%$ & $7 \%$ & $8 \%$ & $7 \%$ & $25 \%$ & $30 \%$ & $28 \%$ \\
\hline Belton et al.^ [30] & 2008 & 301 & $6-9$ & $14 \%$ & $15 \%$ & $15 \%$ & $6 \%$ & $6 \%$ & $6 \%$ & $20 \%$ & $21 \%$ & $21 \%$ \\
\hline Fitzgerald^ [31] & 2008-2009 & 204 & $9-12.9$ & $14 \%$ & $24 \%$ & $17 \%$ & $9 \%$ & $2 \%$ & $5 \%$ & $22 \%$ & $26 \%$ & $24 \%$ \\
\hline HSE Meath, 2009 (unpublished observations)* & 2009 & 1468 & $11-13$ & $17 \%$ & $20 \%$ & $19 \%$ & $4 \%$ & $7 \%$ & $6 \%$ & $22 \%$ & $28 \%$ & $25 \%$ \\
\hline Hollywood et al. [32] & 2009 & 537 & $4-12$ & $15 \%$ & $23 \%$ & $19 \%$ & $12 \%$ & $10 \%$ & $11 \%$ & $27 \%$ & $33 \%$ & $30 \%$ \\
\hline Keane et al. (unpublished observations)* & 2012-2013 & 1068 & $8-11$ & $20 \%$ & $21 \%$ & $20 \%$ & $4 \%$ & $7 \%$ & $5 \%$ & $24 \%$ & $28 \%$ & $25 \%$ \\
\hline
\end{tabular}

\#all prevalence estimates are rounded to the nearest whole number, as a result some numbers may appear not to add but this is due to rounding up or down of prevalence estimates, ^author of study contacted and asked to provide prevalence rates for overweight and obesity using IOTF definitions, ^^^due to the complexity of the WHO European Childhood Obesity Surveillance programme data, only prevalence estimates from the 7 year olds is presented in this current review, ${ }^{*}$ EK conducted the analysis to obtain prevalence estimates of overweight and obesity using IOTF definitions. 
significant trend over time was observed for the national $(\mathrm{p}=0.09)$ studies and a borderline significant trend over time was observed for the regional studies $(p=0.05)$. When overweight and obesity prevalence rates were combined, trends were not significant.

\section{Prevalence of morbid obesity and trends over time}

Morbid obesity prevalence estimates were available for three of the included studies. Based on year of data collection from least to most recently collected data, the prevalence of morbid obesity in each of the three studies was $2.2 \%$ [18], 1.0\%, [Keane et al., unpublished observations] and 0.8\% [HSE Meath, unpublished observations]. The highest prevalence estimate was reported in the earliest (2002) study. The reduction in estimates over time was not significant $(\mathrm{p}=0.2)$.

\section{Prevalence and trends by age and gender}

The prevalence of overweight and obesity in the national studies was consistently higher in girls than boys. Within the included studies, a significant trend over time was observed for obesity rates in girls in all included studies $(\mathrm{p}=0.04)$ but not in boys $(\mathrm{p}=0.2)$. When trends in overweight and obesity prevalence over time were assessed within the studies that collected data in children aged 47.9 years only, 8-13.9 years only and from 4-13.9 years, no significant trends were observed.

\section{Discussion}

\section{Main findings}

This systematic review aimed to synthesize all available overweight and obesity prevalence data from primary school children in the ROI between 2002 and 2012. Fourteen studies (16 prevalence estimates) were included in the review. Due to limited comparability between studies, the results of this review were difficult to interpret. However, similar to trends in other developed countries [11,34], this review suggests that while childhood overweight and obesity prevalence rates remain high in Ireland, prevalence rates appear to be stabilising.

Within the included studies, no trend in overweight prevalence was observed over time. Overweight prevalence varied slightly (non-significant trend) in the nationally based studies with the lowest prevalence of overweight reported in the study where data was collected most recently [14]. This may reflect the age of the included participants rather than a decrease in the prevalence of overweight. The children who participated in the most recent studies $[13,14]$ were 7 years of age. Pubertal maturation is associated with an increased BMI $[5,35]$ and this may partly explain the lower prevalence of overweight and obesity in the later completed study. Alternatively, differences in methodologies between studies may explain findings.
A significant trend over time in obesity prevalence was observed. Obesity prevalence remained constant at $7 \%$ in the nationally based studies between 2002 and 2008 with the prevalence of obesity reducing to $4 \%$ thereafter. The results from the regionally based studies were difficult to interpret and prevalence rates varied considerably between studies. The quality of some of the regional studies or the generalisability of the study populations may act as an explanation. For example, two of the regional studies [25,32] were completed in areas of high social deprivation. Thus, higher prevalence rates may have been estimated in these studies as a lower socioeconomic status is associated with an increased risk of obesity [36].

Morbid obesity data was available for three of the included studies. The results suggest that up to 1 in 50 Irish children are morbidly obese. The lower prevalence of morbid obesity reported in the studies where data was collected most recently may reflect that obesity is receiving increasing attention from the media [37], government organisations [38], and from research institutions. This may have increased awareness of the obesity epidemic in the Irish population and acted as a disincentive for obese children and their parents to participate in studies measuring BMI. Alternatively, the lower prevalence of morbid obesity in the most recent study may reflect a small downward shift in the population distribution of BMI in children in the Irish population [39].

To date, few childhood obesity interventions have been implemented in the ROI and interventions are unlikely to explain why childhood overweight and obesity rates may be stabilising. Recent interventions in the ROI have targeted specific populations such as those who are morbidly obese [40]. Other interventions have targeted specific behaviours associated with obesity including fruit and vegetable consumption [41], physical activity levels [42] or screen time [32]. The magnitude of the problem of childhood overweight and obesity in the ROI requires interventions which should be targeted at a population level. Other explanations for our findings include the relatively short time frame of included studies. A greater time period may be required to observe a clear trend in prevalence rates, especially when comparing studies with different sample sizes, age ranges and using varying methods.

\section{Childhood overweight and obesity rates in other developed countries}

Though the prevalence of childhood obesity appears to have stabilised in a number of countries, the prevalence of overweight and obesity continues to vary significantly between and within countries. The current prevalence of overweight and obesity in the ROI is broadly similar to other European estimates. For example, the ENERGY- 
Project study measured BMI across seven European countries and found that $25.8 \%$ of boys and $21.8 \%$ of girls were overweight or obese though prevalence rates did vary from $14 \%$ in girls from Belgium to $44 \%$ of boys from Greece [43]. However, the findings of this review suggest that the prevalence of overweight and obesity in the ROI is higher in girls than boys. Social and economic factors may help explain why prevalence rates vary between countries. Brug et al. 2012, suggest that socioeconomic factors or cultural factors may play an important role when explaining varying overweight and obesity prevalence rates between countries [44].

\section{Monitoring of overweight and obesity prevalence rates}

Monitoring childhood obesity prevalence rates is an important public health measure. In the ROI, trends in childhood overweight and obesity had not been routinely monitored prior to the introduction of the WHO European Childhood Obesity Surveillance programme in 2008. Three phases of WHO surveillance data have now been collected in 2008, 2010 and 2012 [13]. Over time, this data will create a national database which will be comparable to surveillance data collected in other European counties [45].

All children in senior infants (year two of enrolment) in primary schools in the ROI receive a health check. Measurement of height and weight is to be included in a small subsample of schools. Based on this pilot project, height and weight may be added to this routine health check. This would provide valuable information on the height and weight of Irish children. However, ongoing surveillance initiatives do not reduce the value of other studies collecting objective height and weight data though it is essential that methods used between studies are standardised.

\section{Recommendations for study reporting}

This review has resulted in two recommendations for study reporting. Firstly, confidence intervals or standard errors should be reported with prevalence estimates. This did not commonly occur in the included studies. Secondly, studies should provide sufficient detail which would allow for replication of the methods used.

\section{Strengths and limitations}

A comprehensive search strategy was used to locate relevant literature and contact with obesity experts in Ireland resulted in some additional studies being identified. A critical appraisal tool was adapted to assess the quality and potential sources of bias within each included study. However, a standard critical appraisal tool to access the quality of studies reporting prevalence estimates needs to be developed. This review also has a number of limitations. The interpretation of the findings of this review was difficult due to varying methods used in the included studies. As detailed above, few of the included studies reported confidence intervals or standard errors. It was therefore difficult to interpret the accuracy of the point estimates.

\section{Conclusion}

Though this review includes studies from a relatively short, 10 year time frame, the prevalence of overweight and obesity in school aged children in the ROI appears to be stabilising. In the absence of routinely measured data from large and representative population samples, we urge caution in the interpretation of these findings. There is a clear need to agree and disseminate standardised operating procedures and methods for the conduct of studies on the prevalence of overweight and obesity in childhood with particular reference to the issues of sampling and response rates. Although the findings provide some grounds for cautious optimism, one in four Irish children remains overweight or obese. Thus, it is clear that childhood overweight and obesity will remain an urgent priority issue for public policy for the foreseeable future.

\section{Additional files}

Additional file 1: Supplementary information on the search strategy for a systematic review.

Additional file 2: Supplementary information on critical appraisals for a systematic review.

\section{Abbreviations}

BMI: Body mass index; COSI: Childhood obesity surveillance initiative; HSE: Health Service Executive; IOTF: International Obesity Taskforce; PPS: Probability proportionate to size; ROI: Republic of Ireland; WHO: World Health Organization.

\section{Competing interests}

The authors declare that they have no competing interests.

\section{Authors' contributions}

All authors were involved in the design of this systematic review. EK drafted the manuscript and conducted the statistical analysis. EK and JMH carried out the quality appraisals. All authors were involved in revising the manuscript and approved the final draft.

\section{Acknowledgements}

The authors would like to thank the all obesity experts and corresponding authors who responded to our emails. We would like to thank (1) Dr Mary O'Farrell, Principal Dental Surgeon, Health Services Executive Louth Meath for providing us with the Oral health survey, Meath dataset and (2) Virginia Kelleher and her colleagues in the Oral Health Services Research Centre, Cork for providing us with the North South Survey of Children's Oral Health study dataset. We would like to thank Dr. Paul Beirne and Mr. Cathal Kerrigan for their advice. We would like to thank HRB Centre for Health and Diet Research for supporting this research (http://www.ucc.ie/en/hrbc/). This research was funded by the National Children's Research Centre, Crumlin, Dublin (http://www.nationalchildrensresearchcentre.ie/project/view/35).

\section{Author details}

'Department of Epidemiology and Public Health, University College Cork, Fourth Floor, Western Gateway Building, Western Road, Cork, Republic of Ireland. ${ }^{2}$ School of Public Health, Physiotherapy and Population Science, University College Dublin, Dublin, Republic of Ireland. 
Received: 5 June 2014 Accepted: 11 September 2014

Published: 14 October 2014

\section{References}

1. World Health Organization: Obesity: preventing and managing the global epidemic. In Technical Report Series. Geneva: World Health Organization; 2000:894.

2. Ebbeling CB, Pawlak DB, Ludwig DS: Childhood obesity: public-health crisis, common sense cure. Lancet 2002, 360(9331):473-482.

3. Ogden CL, Yanovski SZ, Carroll MD, Flegal KM: The Epidemiology of Obesity. Gastroenterology 2007, 132(6):2087-2102.

4. Wang Y, Lobstein T: Worldwide trends in childhood overweight and obesity Int J Pediatr Obes 2006, 1(1):11-25

5. Lobstein T, Baur L, Uauy R: Obesity in children and young people: A crisis in public health. Obes Rev 2004, 5(1):4-104.

6. Ogden $\mathrm{CL}$, Flegal KM, Carroll MD, Johnson CL: Prevalence and trends in overweight among US children and adolescents, 1999-2000. JAMA 2002, 288(14):1728-1732.

7. Jackson-Leach R, Lobstein T: Estimated burden of paediatric obesity and co-morbidities in Europe. Part 1. The increase in the prevalence of child obesity in Europe is itself increasing. Int J Pediatr Obes 2006, 1(1):26-32.

8. Morgen CS, Rokholm B, Brixval CS, Andersen CS, Andersen LG, Rasmussen M, Andersen A-MN, Due P, Sørensen TI: Trends in Prevalence of Overweight and Obesity in Danish Infants, Children and Adolescents-Are We Still on a Plateau? PLoS One 2013, 8(7):e69860.

9. Bergström E, Blomquist HK: Is the prevalence of overweight and obesity declining among 4-year-old Swedish children? Acta Pædiatrica 2009, 98(12):1956-1958.

10. Olds T, Maher C, Zumin S, Péneau S, Lioret S, Castetbon K, Wilde J, Hohepa M, Maddison R, Lissner L: Evidence that the prevalence of childhood overweight is plateauing: data from nine countries. Int J Pediatr Obes 2011, 6(5-6):342-360

11. Rokholm B, Baker J, Sørensen T: The levelling off of the obesity epidemic since the year 1999-a review of evidence and perspectives. Obesity reviews 2010, 11(12):835-846.

12. Perry IJ, Whelton $H$, Harrington J, Cousins B: The heights and weights of Irish children from the post-war era to the Celtic tiger. J Epidemiol Community Health 2009, 63(3):262-264.

13. Heavey P, McGloin A, Kilroe J, Daly L, O'Mahony D, Kelleher C: Childhood Obesity Surveillance Initiative in Ireland. Main Report. Ireland, Dublin: Health Service Executive and Department of Health and Children; 2009.

14. Heinen MM, Murrin C, Daly L, O'Brien J, Heavey P, Kilroe J, O'Brien M, Scully H, Mulhern LM, Lynam A, Hayes C, O'Dwyer U, Eldin N, Kelleher C: The Childhood Obesity Surveillance Initiative (COSI) in the Republic of Ireland: Findings from 2008 2010 and 2012. Ireland, Dublin: Health Service Executive; 2014

15. Cole TJ, Bellizzi MC, Flegal KM, Dietz WH: Establishing a standard definition for child overweight and obesity worldwide: international survey. BMJ 2000 320(7244):1240

16. Radulescu M, Diepgen T, Williams HC: What makes a good prevalence survey? In Evidence-Based Dermatology. 2nd edition. Edited by Williams HC, Bigby M, Diepgen T, Herxheimer A, Naldi L, Rzany B. Blackwell Publishing: Oxford; 2009:61-67.

17. Vidmar S, Carlin J, Hesketh $\mathrm{K}$, Cole T: Standardizing anthropometric measures in children and adolescents with new functions for egen. Stata J 2004, 4(1):50-55

18. Whelton $\mathrm{H}$, Harrington J, Crowley E, Kelleher V, Cronin M, Perry I: Prevalence of overweight and obesity on the island of Ireland: results from the North South Survey of Children's Height, Weight and Body Mass Index, 2002. BMC Public Health 2007, 7(1):187.

19. Cole TJ, Lobstein T: Extended international (IOTF) body mass index cut-offs for thinness, overweight and obesity. Pediatric Obesity 2012, 7(4):284-294.

20. Williams J, Greene S, Doyle E, Harris E, Layte R, McCoy R: Growing Up in Ireland. The Lives of 9-Year-Olds. Report 1. Office of the Minister for Children and Youth Affairs: Ireland, Dublin; 2009.

21. Whelton H, Harrington J, Crowley E, Kelleher V, Cronin M, Perry IJ: North South Survey of children's Height, Weight and Body Mass Index. Ireland, Dublin: Department of Health and Children; 2002:2006.

22. O'Neill JL, McCarthy SN, Burke SJ, Hannon EM, Kiely M, Flynn A, Flynn MAT, Gibney MJ: Prevalence of overweight and obesity in Irish school children, using four different definitions. Eur J Clin Nutr 2007, 61(6):743-751.

23. Layte R, McCrory C: Growing Up in Ireland-Overweight and Obesity among 9-yearolds. Ireland, Dublin: Department of Children and Youth Affairs; 2011.

24. McMaster C, Cullen L, Raymond N: Overweight and obesity in Irish primary schools: Retrospective cohort study. Child Care Health Dev 2005, 31(5):499-506.
25. Harrison M, Burns CF, McGuinness M, Heslin J, Murphy NM: Influence of a health education intervention on physical activity and screen time in primary school children: 'Switch Off-Get Active'. J Sci Med Sport 2006, 9(5):388-394.

26. Evans DS, Glacken M, Goggin D: Childhood obesity: the extent of the problem among 6-year-old Irish national school children. Child Care Health Dev 2011 37(3):352-359.

27. Barron C, Comiskey C, Saris J: Prevalence rates and comparisons of obesity levels in Ireland. Br J Nurs 2009, 18(13):799-803.

28. Murrin CM, Kelly GE, Tremblay RE, Kelleher CC: Body mass index and height over three generations: evidence from the Lifeways cross-generational cohort study. BMC Public Health 2012, 12(1):81.

29. O'Mahony D, Fallon U, Hannon F, Kloeckner K, Avalos G, Murphy A, Kelleher C: The Lifeways Cross-Generation Study: design, recruitment and data management considerations. Ir Med J 2007, 100(8):suppl 3.

30. Belton S, Brady P, Meegan S, Woods C: Pedometer step count and BMI of Irish primary school children aged 6-9 years. Prev Med 2010, 50(4):189-192.

31. Fitzgerald A: Psychological and social factors in predicting children's food choices: The development of a theoretical model. In PhD Thesis. Galway: National University of Ireland; 2010.

32. Hollywood E, Comiskey C, Begley T, Snel A, O'Sullivan K, Quirke M, Wynne C: Measuring and modelling body mass index among a cohort of urban children living with disadvantage. J Adv Nurs 2013, 69(4):851-861.

33. Glacken M, Evans DS: Measuring Height and Weight in School Children as a Public Health Indicator. Ireland, Galway: Department of Public Health, Health Services Executive West; 2006.

34. Wabitsch M, Moss A, Kromeyer-Hauschild K: Unexpected plateauing of childhood obesity rates in developed countries. BMC Medicine 2014, 12(1):17.

35. Wright CM, Emmett PM, Ness AR, Reilly JJ, Sherriff A: Tracking of obesity and body fatness through mid-childhood. Arch Dis Child 2010, 95(8):8.

36. Keane E, Layte R, Harrington J, Kearney PM, Perry IJ: Measured parental weight status and familial socio-economic status correlates with childhood overweight and obesity at age 9. PLoS One 2012, 7(8):e43503.

37. De Brún A, McKenzie K, McCarthy M, McGloin A: The Emergence and Portrayal of Obesity in The Irish Times: Content Analysis of Obesity Coverage, 1997-2009. Health Communication 2012, 27(4):389-398.

38. Department of Health and Children: Obesity: The Policy Challenges -The Report of the National Taskforce on Obesity 2005. Ireland, Dublin: Department of Health and Children; 2005

39. Rose G: Sick individuals and sick populations. Int J Epidemiol 2001, 30(3):427-432.

40. O'Malley G, Clarke M, Burls A, Murphy S, Murphy N, Perry IJ: A smartphone intervention for adolescent obesity: study protocol for a randomised controlled non-inferiority trial. Trials 2014, 15(1):43.

41. Horne P, Hardman C, Lowe C, Tapper K, Le Noury J, Madden P, Patel P, Doody M: Increasing parental provision and children's consumption of lunchbox fruit and vegetables in Ireland: the Food Dudes intervention. Eur J Clin Nutr 2009, 63(5):613-618.

42. Murtagh E, Mulvihill M, Markey O: Bizzy Break! The effect of a classroom-based activity break on in-school physical activity levels of primary school children. Pediatr Exerc Sci 2013, 25(2):300.

43. Brug J, van Stralen MM, te Velde SJ, Chinapaw MJ, De Bourdeaudhuij I, Lien N, Bere E, Maskini V, Singh AS, Maes L: Differences in weight status and energybalance related behaviors among schoolchildren across Europe: the ENERGY-project. PLoS One 2012, 7(4):e34742.

44. Brug J, van Stralen MM, ChinApaw MJM, De Bourdeaudhuij I, Lien N, Bere E, Singh AS, Maes L, Moreno L, Jan N, Kovacs E, Lobstein T, Manios Y, te Velde SJ: Differences in weight status and energy-balance related behaviours according to ethnic background among adolescents in seven countries in Europe: the ENERGY-project. Pediatric Obesity 2012, 7(5):399-411.

45. Wijnhoven TMA, Van Raaij JMA, Spinelli A, Rito Al, Hovengen R, Kunesova M, Starc G, Rutter H, Sjoberg A, Petrauskiene A, O'Dwyer U, Petrova S, Sant'Angelo VF, Wauters M, Yngve A, Rubana IM, Breda J: Who European childhood obesity surveillance initiative: Inter-country results from first 12 who member states. Obesity Facts 2012, 5:13-14.

doi:10.1186/1471-2458-14-974

Cite this article as: Keane et al.: Trends and prevalence of overweight and obesity in primary school aged children in the Republic of Ireland from 2002-2012: a systematic review. BMC Public Health 2014 14:974. 